\title{
PHYSIOLOGICAL ADJUSTMENT OF ARTERIAL BLOOD GASES AND BICARBONATE ION DURING PREGNANCY IN HUMAN
}

\author{
DIPOK KUMAR SUNYAL ${ }^{1}$, MD. RUHUL AMIN² ${ }^{2}$ ABIDAAHMED ${ }^{3}$, MIR RABAYAAKHTER ${ }^{4}$, GOLAM MORSHED MOLLA $^{5}$, \\ ABM OMAR FARUQUE ${ }^{6}$
}

Assistant Professor, Department of Physiology, Enam Medical College, Savar, Dhaka ${ }^{1}$, Professor, Department of Physiology, Dhaka Medical College, Dhaka², Professor, Department of Physiology, Comilla Medical College, Comilla $^{3}$, Assistant Registrar, Department of Gynaecology and Obstetrics, Moulana Bhasani Medical College and Hospital, Dhaka ${ }^{4}$, Assistant Professor, Department of Biochemistry, Enam Medical College, Savar, Dhaka ${ }^{5}$, Assistant Professor, Department of Anatomy, Tairunnessa Memorial Medical College, Gazipur ${ }^{6}$

\begin{abstract}
In the present study the partial pressure of oxygen $\left(\mathrm{PaO}_{2}\right)$, carbon dioxide $\left(\mathrm{PaCO}_{2}\right)$ and bicarbonate ion (HCO3-) in arterial blood were estimated in 32 women in Dhaka city. For this purpose a total of 32 women subjects with age ranged from 25 years to 35 years without any recent history of respiratory diseases were selected. Of those, 8 healthy non-pregnant women were included as control and 24 normal pregnant women as experimental group. The $\mathrm{PaO}_{2} \mathrm{PaCO}_{2}$ and $\mathrm{HCO}_{3}$ were estimated during the first, second and third trimester by using 'easy blood gas auto analyzer'. The $\mathrm{PaO}_{2}$ was significantly higher during entire pregnancy period. However, the $\mathrm{PaCO}_{2}$ and $\mathrm{HCO}_{3}$-were significantly lower in first, second and third trimester of pregnant women than that of non-pregnant women. There were no statistically significant difference of $\mathrm{PaO}_{2} \mathrm{PaCO}_{2}$ and $\mathrm{HCO}_{3}$ ion among first trimester, second trimester and third trimester. The progressively increased $\mathrm{PaO}_{2}$, decreased $\mathrm{PaCO}_{2}$ and $\mathrm{HCO}_{3}$ ion throughout the pregnancy is possibly due to the effect of progesterone causing hyperventilation.
\end{abstract}

(Bangladesh J Physiol Pharmacol 2007; 23(1\&2) : 10-12)

\section{INTRODUCTION}

During normal pregnancy hyperventilation and increased respiratory minute volume result in decreased maternal alveolar and blood $\mathrm{PCO}_{2}$. In pregnant women progesterone may act directly on the respiratory centers and cause hyperventilation ${ }^{1}$. Progesterone can also induce changes in smooth muscle tone and connective tissue elastance which may alter the mechanical properties of the respiratory system ${ }^{2}$. It has been well documented that maternal ventilation and blood gases undergo substantial changes in pregnancy. There was a $40 \%$ increased in minute ventilation resulting in a rise in $\mathrm{PaO}_{2}$ and fall in $\mathrm{PaCO}_{2}$ and $\mathrm{HCO}_{3}{ }^{-}$. This increased ventilation is thought to be mediated by progesterone which lowers the threshold of respiratory center and increases the sensitivity of the respiratory center. Several other studies have shown that hyperventilation during pregnancy causes increase in $\mathrm{PaO}_{2}$, decrease in $\mathrm{PaCO}_{2}$ and a compensatory fall in serum bicarbonate ion in pregnant women $n^{5,6,7}$. It is therefore important physiologically as well as clinically to observe the $\mathrm{PaO}_{2}$, $\mathrm{PaCO}_{2}$ and $\mathrm{HCO}_{3}{ }^{-}$in pregnant women. Although several studies have been carried out in different populations no established data is available in Bangladeshi population. In the present study we evaluated the changes in $\mathrm{PaO}_{2}$,

Address of Correspondence: Dr. Dipok Kumar Sunyal, Assistant Professor, Department of Physiology, Enam Medical College, Savar, Dhaka
$\mathrm{PaCO}_{2}$ and $\mathrm{HCO}_{3}-$ during the different trimesters of normal pregnant women and healthy non-pregnant women in Dhaka city.

\section{MATERIALS AND METHODS}

The $\mathrm{PaO}_{2}, \mathrm{PaCO}_{2}$ and $\mathrm{HCO}^{-}$ion was measured in normal pregnant and healthy non-pregnant women. For this purpose 32 subjects were recruited among which 8 non-pregnant women were selected as control and 24 pregnant women as experimental group with age ranged from 25 years to 35 years. Experimental group was further divided into first trimester $(n=8)$, second trimester $(n=8)$ and third trimester $(n=8)$ of pregnant women. All the subjects were taken from different areas of Dhaka city that belonged to lower-middle and poor socioeconomic classes. The subjects were selected by careful history taking and physical examination which revealed no evidence of past or recent significant respiratory diseases.

The measurement of $\mathrm{PaO}_{2}, \mathrm{PaCO}_{2}$ and $\mathrm{HCO}^{-}$were done both in healthy non-pregnant women and normal pregnant women during first trimester (1st to 12th weeks), second trimester (13th to 28th weeks) and third trimester (29th to 40th weeks). The $\mathrm{PaO}_{2}, \mathrm{PaCO}_{2}$ and $\mathrm{HCO}^{-}$were measured by "easy blood gas auto analyzer". The mean of measured values of $\mathrm{PaO}_{2}, \mathrm{PaCO}_{2}$ and $\mathrm{HCO}^{-}$" were statistically analyzed by unpaired Student's " $t$ " test between and among the study groups. A $p$ value $<0.05$ was accepted as significant. 


\section{RESULTS}

The mean $( \pm S D)$ of measured values of $\mathrm{PaO}_{2}$ were $86.38 \pm 5.37,98.13 \pm 11.01,102.00 \pm 9.13$ and $106.50 \pm 4.38$ in non-pregnant control women and in pregnant women during first, second and third trimester (table-I). The mean $( \pm S D)$ of measured values of $\mathrm{PaO}_{2}$ were significantly higher in first trimester, second trimester and third trimester of pregnant women than that of non-pregnant women as shown in table-II and Figure 1.

The mean ( \pm SD) of measured values of $\mathrm{PaCO}_{2}$ were $36.89 \pm 3.70,32.73 \pm 3.16,32.46 \pm 3.61$ and $31.03 \pm 3.20$ in non-pregnant women and in pregnant women during first trimester, second trimester and third trimester (tableIII). The mean ( \pm SD) of measured values of $\mathrm{PaCO}_{2}$ were significantly lower in first trimester, second trimester and third trimester of pregnant women than that of nonpregnant women as shown in table-IV and Figure 2.

On the other hand, the mean $( \pm S D)$ of measured values of $\mathrm{HCO}_{3}^{-}$were 23.61 $2.05,21.68 \pm 1.45$, $21.53 \pm 1.80$ and $21.13 \pm 1.47$ in non-pregnant women and in pregnant women during first trimester, second trimester and third trimester (table-V). The mean ( $\pm S D$ ) of measured values of $\mathrm{HCO}_{3}{ }^{-}$were significantly lower in first trimester, second trimester and third trimester of pregnant women than that of non-pregnant women as shown in table-VI and Figure 3.

The $\mathrm{PaO}_{2}$ value was gradually increased, the $\mathrm{PaCO}_{2}$ and $\mathrm{HCO}_{3}{ }^{-}$value were gradually decreased during pregnancy from first trimester to third trimester than that of non-pregnant women.

There were no statistically significant difference of $\mathrm{PaO}_{2}, \mathrm{PaCO}_{2}$ and $\mathrm{HCO}_{3}^{-}$ion among first trimester, second trimester and third trimester of pregnant women.

Table -I

The mean $( \pm S D)$ of measured values of $\mathrm{PaO}_{2}$ in different groups of subjects

\begin{tabular}{llc}
\hline Groups & $\mathrm{n}$ & Measured value $(\mathrm{mm} \mathrm{Hg})$ \\
\hline A & 8 & $86.38 \pm 5.37$ \\
B-I & 8 & $98.13 \pm 11.01$ \\
B-II & 8 & $102.00 \pm 9.13$ \\
B-III & 8 & $106.50 \pm 4.38$ \\
\hline
\end{tabular}

$A=$ Control (healthy non-pregnant women)

$\mathrm{B}-\mathrm{I}=$ Pregnant women, $1^{\text {st }}$ trimester

$\mathrm{B}-\mathrm{II}=$ Pregnant women, $2^{\text {nd }}$ trimester

$\mathrm{B}-\mathrm{III}=$ Pregnant women, 3rdtrimester

$\mathrm{n}$ : number of subjects

$P$ values were obtained by unpaired Student's " $t$ " test

* = significant ${ }^{* \star *}=$ highly significant

$\mathrm{ns}=$ not significant
Table-II

The statistical analysis of mean $( \pm S D)$ of measured values of $\mathrm{PaO}_{2}$ in different groups of subjects

Statistical Analysis (measured value)

\begin{tabular}{ll} 
Groups comparison & P value \\
\hline A vs B-I & $<0.05^{*}$ \\
A vs B-II & $<0.001^{* * *}$ \\
A vs B-III & $<0.001^{* * *}$ \\
B-I vs B-II & $>0.10^{\text {ns }}$ \\
B-I vs B-III & $>0.05^{\text {ns }}$ \\
B-II vs B-III & $>0.10^{\text {ns }}$ \\
\hline
\end{tabular}

Table -III

The mean $( \pm S D)$ of measured values of $\mathrm{PaCO}_{2}$ in different groups of subjects

\begin{tabular}{llc}
\hline Groups & $\mathrm{n}$ & Measured value $(\mathrm{mm} \mathrm{Hg})$ \\
\hline A & 8 & $36.89 \pm 3.70$ \\
B-I & 8 & $32.73 \pm 3.16$ \\
B-II & 8 & $32.46 \pm 3.61$ \\
B-III & 8 & $31.03 \pm 3.20$ \\
\hline
\end{tabular}

$A=$ Control (healthy non-pregnant women)

B-I = Pregnant women, $1^{\text {st }}$ trimester

$\mathrm{B}-\mathrm{II}=$ Pregnant women, $2^{\text {nd }}$ trimester

B-III = Pregnant women, 3rdtrimester

$\mathrm{n}$ : number of subjects

$P$ values were obtained by unpaired Student's "t" test

* = significant ${ }^{* *}=$ highly significant

ns $=$ not significant

Table-IV

The statistical analysis of mean ( $\pm S D$ ) of measured values of $\mathrm{PaCO}_{2}$ in different groups of subjects

\begin{tabular}{lc}
\hline \multicolumn{2}{c}{ Statistical Analysis (measured value) } \\
Groups comparison & P value \\
\hline A vs B-I & $<0.05^{\star}$ \\
A vs B-II & $<0.05^{\star}$ \\
A vs B-III & $<0.01^{\star *}$ \\
B-I vs B-II & $>0.50^{\mathrm{ns}}$ \\
B-I vs B-III & $>0.10^{\mathrm{ns}}$ \\
B-II vs B-III & $>0.10^{\mathrm{ns}}$ \\
\hline
\end{tabular}


Table -V

The mean $( \pm S D)$ of measured values of $\mathrm{HCO}_{3}{ }^{-}$in different groups of subjects

\begin{tabular}{llc}
\hline Groups & $\mathrm{n}$ & Measured value $(\mathrm{mm} \mathrm{Hg})$ \\
\hline A & 8 & $23.61 \pm 2.05$ \\
B-I & 8 & $21.68 \pm 1.45$ \\
B-II & 8 & $21.53 \pm 1.80$ \\
B-III & 8 & $21.13 \pm 1.47$ \\
\hline
\end{tabular}

$\mathrm{A}=$ Control (healthy non-pregnant women)

$\mathrm{B}-\mathrm{I}=$ Pregnant women, $1^{\text {st }}$ trimester

B-II = Pregnant women, $2^{\text {nd }}$ trimester

$\mathrm{B}-\mathrm{III}=$ Pregnant women, 3rdtrimester

$\mathrm{n}$ : number of subjects

$\mathrm{P}$ values were obtained by unpaired Student's " $\mathrm{t}$ " test

* $=$ significant ${ }^{* *}=$ highly significant

ns $=$ not significant

Table-VI

The statistical analysis of mean $( \pm S D)$ of measured values of $\mathrm{HCO}_{3}{ }^{-}$in different groups of subjects Statistical Analysis (measured value)

\begin{tabular}{ll}
\hline Groups comparison & P value \\
\hline A vs B-I & $<0.05^{*}$ \\
A vs B-II & $<0.05^{*}$ \\
A vs B-III & $<0.05^{*}$ \\
B-I vs B-II & $>0.50^{\text {ns }}$ \\
B-I vs B-III & $>0.10^{\text {ns }}$ \\
B-II vs B-III & $>0.50^{\text {ns }}$ \\
\hline
\end{tabular}

\section{DISCUSSION}

In the present study the measured values of $\mathrm{PaO}_{2}$ were significantly higher during all the trimesters than that of non-pregnant women. Similarly the measured values of $\mathrm{PaCO}_{2}$ and $\mathrm{HCO}_{3}{ }^{-}$were significantly lower in first, second and third trimester than that of non-pregnant women. The $\mathrm{PaO}_{2}$ gradually increased and the $\mathrm{PaCO}_{2}$ and $\mathrm{HCO}_{3}{ }^{-}$were gradually decreased throughout the pregnancy from first to third trimester of pregnant women. Results of the present study are in agreement with other studies $^{4-10}$.

It has been previously shown that the $\mathrm{PO}_{2}$ is higher

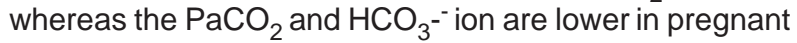
women at sea level compared with the non-pregnant women due to maternal hyperventilation. There is also an increase in minute ventilation resulting in a rise in $\mathrm{PaO}_{2}$, fall in $\mathrm{PaCO}_{2}$ and $\mathrm{HCO}_{3}{ }^{-}$. This increased ventilation is thought to be mediated by progesterone which lowers the threshold of respiratory center and increases the sensitivity the respiratory centre ${ }^{4}$. It has also been demonstrated that pregnancy is associated with an increase in ventilation which consequently increases the $\mathrm{PaO}_{2}$ and decreases $\mathrm{PaCO}_{2}{ }^{5}$. Normal pregnancy is associated with a $20 \%$ increase in $\mathrm{O}_{2}$ consumption and a $15 \%$ increase in the maternal metabolic rate. This extra demand is achieved via $40-50 \%$ increase in resting minute ventilation which causes the $\mathrm{PaO}_{2}$ to increase and the $\mathrm{PaCO}_{2}$ and $\mathrm{HCO}_{3}{ }^{-}$to falls ${ }^{7}$.

In this study, though the $\mathrm{PaO}_{2}$ was significantly higher, the $\mathrm{PaCO}_{2}$ and $\mathrm{HCO}_{3}{ }^{-}$were significantly lower in first, second and third trimester of pregnant women than that of non-pregnant women. This can be speculated that maternal hyperventilation due to the effect of progesterone is possibly associated with the increased $\mathrm{PaO}_{2}$ but decreased $\mathrm{PaCO}_{2}$ and $\mathrm{HCO}_{3}^{-}$during pregnancy.

\section{REFERENCES}

1. DeCherney $\mathrm{AH}$ and Pernoll. Maternal physiology during pregnancy. In : Current Obstetrics \& Gynaecologic Diagnosis \& Treatment. Ninth Edition. 2003 : 159-160.

2. Gee L J B, Packer B S, Millen E et al. Pulmonary mechanics during pregnancy. Journal of Clinical Investigation. 1967 ; 46 (6) : 945-952.

3. Spiropoulos K, Prodromaki E, Tsapanos V. Effect of body position on $\mathrm{PaO}_{2}$ and $\mathrm{PaCO}_{2}$ during pregnancy. Gynecol Obstet Invest $2004 ; 58$ : 22-25.

4. McAuliffe F, Kametas N, Krampl E, Ernsting J, Nicolaides $\mathrm{K}$. Blood gases in pregnancy at sea level and at high altitude. BJOG. $2001 ; 108: 980-985$.

5. McAuliffe FM, Kametas N, Costello J, Rafferty G F, Greenough A, Nicolaides K. Respiratory function in singleton \& twin pregnancy. BJOG. $2002 ; 109$ : 765769.

6. McAuliffe F, Kametas N, Espirioza J, Greenough A, Nicolaides $\mathrm{K}$. Respiratory function in pregnancy at sea level \& at high altitude. BJOG. $2004 ; 111$ : 311-315.

7. Piercy $\mathrm{C}$ Nelson. Respiratory diseases in pregnancy. Thorax $2001 ; 56: 325-328$.

8. Rasheed $\mathrm{B}$, Hussain $\mathrm{K}$ and Hussain S. PEFR in relation to phases of pregnancy. Indian J Physiol Pharmacol 2000 ; 44 (4) : 511-512.

9. Hankins GD, Clark SL, Harvey CJ et al. Third trimester arterial blood gas and acid base values in normal pregnancy at moderate altitude. Obstet Gynecol 1996 ; 88 (3) : 347-350

10. Singhal $U$ and Saxena K. Effect of anaemia on respiratory and metabolic parameters during third trimester of pregnancy. Indian J Physiol Pharmacol 1987 ; 31(2) : 130135.

11. Prodromakis E, Trakada G, Tsapanos V, Spiropoulos K. Arterial oxygen tension during sleep in the third trimester of pregnancy. Acta Obstet Gynecol Scand 2004 ; 83 : 159-164.

12. Trakada G, Tsapanos V, Spiropoulos K. Normal pregnancy and oxygenation during sleep. Eur J Obstet Gynecol Reprod Biol 2003 ; 109 : 128-132. 